\title{
COPOLYMERIZATION OF POLY (O-PHENYLENEDIAMINE-CO-O/P-TOLUIDINE) VIA THE CHEMICAL OXIDATIVE TECHNIQUE: SYNTHESIS AND CHARACTERIZATION
}

\author{
KOPOLIMERIZACIJA POLI \\ (O-FENILENDIAMINA-CO-O/P-TOLUIDINA) S TEHNIKO \\ KEMIJSKE OKSIDACIJE: SINTEZA IN KARAKTERIZACIJA
}

\author{
Omar Melad, Mariam Jarour \\ Al-Azhar University Gaza, Chemistry Department, P.O.Box 1277, Gaza, Palestine \\ omarmelad@yahoo.com \\ Prejem rokopisa - received: 2016-01-23; sprejem za objavo - accepted for publication: 2016-03-16
}

doi: $10.17222 /$ mit.2016.023

\begin{abstract}
Chemical oxidative copolymerization of $o$-phenylenediamine -co-o/p-toluidine at different molar ratios of monomer was performed using potassium dichromate as an oxidant. The resulting copolymers were investigated using Fourier transform infrared spectroscopy (FTIR) and UV-visible spectroscopy. In the copolymer, the intensity of the band at $1005 \mathrm{~cm}^{-1}$ is substantially decreased due to the $-\mathrm{CH}_{3}$ bending vibrations. A hyposochromic shift is observed in UV-visible spectroscopy. The electrical-conductivity values obtained for the $o$-toluidine copolymers are higher than those for the $p$-toluidine copolymers. Keywords: $o$-phenylenediamine, $o$-toluidine, $p$-toluidine, conductivity, chemical oxidativeness, FTIR

Izvedena je bila kemijska oksidativna kopolimerizacija $o$-fenilendiamina-co-o/p-toluidina pri različnih molarnih razmerjih monomera, z uporabo kalijevega dikromata kot oksidanta. Nastali kopolimeri so bili preiskovani z uporabo infrardeče spektroskopije s Fourierjevo transformacijo (FTIR) in UV-vidno spektroskopijo. V kopolimeru je intenziteta pasu pri $1005 \mathrm{~cm}^{-1}$ občutno zmanjšana zaradi upogibnih vibracij $-\mathrm{CH}_{3}$. V UV vidnem spektru je opažen zamik v spektralnem pasu. Vrednosti električne prevodnosti dobljene pri $o$-toluidin kopolimerih so višje kot pri $p$-toluidin kopolimerih.

Ključne besede: $o$-fenilendiamin, $o$-toluidin, $p$-toluidin, prevodnost, kemijska oksidativnost, FTIR
\end{abstract}

\section{INTRODUCTION}

Intrinsically conductive polymers have become an efficient alternative to inorganic conductors in many practical applications in the recent decade. ${ }^{1}$ Polyaniline, poly toluidine, polypyrrole, poly aminopyridine, polythiophene and poly phenylenediamine are examples of conductive polymers, showing high conductivity. Polyaniline is an important member of the intrinsically conductive polymers because of the ease of its preparation, an excellent environmental stability, interchangeable oxidation states, electrical and optical properties, economic costs, ${ }^{2-4}$ and because they can be used for chemical sensors, ${ }^{5,6}$ electromagnetic shielding, ${ }^{7}$ electrochemical and corrosion devices. ${ }^{8-9}$ Polymerization of a conducting polymer may be performed with chemical ${ }^{10}$ or electrochemical ${ }^{11}$ methods. Different chemical oxidizing agents such as potassium dichromate, ${ }^{12-14}$ potassium iodate, ${ }^{15}$ hydrogen peroxide, ${ }^{16}$ ferric chloride or ammonium persulphate ${ }^{17}$ can be used. The application of polyaniline is limited because of its poor processability, ${ }^{18}$ which is true for most conducting polymers.

A good method to obtain soluble conductive polymers is the polymerization of aniline derivatives. Poly phenylenediamine homopolymer has attracted attention because it has been reported to be a high aromatic polymer containing a 2,3-diamino phenazine or quinoxaline repeat unit and exhibiting an unusually high thermostability. ${ }^{19-21}$ In recent years, copolymerization has been developed as one of the most essential and alternative strategies for modifying physical and chemical properties of conducting polymers. These copolymers show characteristics reasonably different from those of the homo polymer. ${ }^{22,23}$ Thus, copolymerization can be a convenient synthetic method and a process for preparing new conducting materials with improved properties. However, the conductivity and solubility of the phenylenediamine homopolymer are low. ${ }^{19-21} \mathrm{Co}-$ polymerization of o-phenylenediamine with $\mathrm{o} / \mathrm{p}$ toluidine might be one of the best methods. A close analysis of the literature shows a large number of reports on the chemical and electrochemical synthesis of polytoluidine and its copolymer with aniline and other substituted anilines. ${ }^{24-33}$ Electrochemical copolymerization of o-phenylenediamine with $o$-toluidine has been reported. ${ }^{34}$ So far, there has been no report on copolymerization of o-phenylenediamine with $o / p$ toluidine using the chemical oxidative method. Toluidines are derivatives of aniline where a $-\mathrm{CH}_{3}$ group is substituted in the aromatic ring 
at the $o^{-}, m$ - or $p$ - positions. In this work, a chemical oxidative copolymerization of o-phenylenediamine with $o / p$ toluidine at different molar ratios of monomer was synthesized and characterized using FTIR, UV-visible spectroscopy and conductivity measurements.

\section{EXPERIMENTAL PART}

\subsection{Materials}

o-phenylenediamine (o-PD), o-touidine $(o \mathrm{~T})$, p-toluidine $(p \mathrm{~T})$ (ADWIC, Egypt), potassium dichromate $\left(\mathrm{K}_{2} \mathrm{Cr}_{2} \mathrm{O}_{7}\right)$, ammonium persulfate $\left(\left(\mathrm{NH}_{4}\right)_{2} \mathrm{~S}_{2} \mathrm{O}_{3}\right)$ (Merk, Germany), hydrochloric acid ( $\mathrm{HCl} 32 \%)$, formic acid ( $\mathrm{HCOOH} 98 \%)$ and glacial acetic acid $\left(\mathrm{CH}_{3} \mathrm{COOH} 99.5 \%\right)$ (Merk-Germany), dimethylsulfoxide (DMSO) and $\mathrm{N}, \mathrm{N}$-dimethylformamide (DMF) were used for the UV-visible and conductivity measurements, respectively. All the chemicals, acids and solvents were used as received without any further purification.

\subsection{Measurements}

The FTIR spectra were recorded with a FTIR 8201PC (SHIMADZU) instrument using $\mathrm{KBr}$ pellets techniques. For measuring the UV-visible absorption spectra, a spectrophotometer (UV-1601 SHIMADZU) was used. Conductivity measurements were made at room temperature using a conductivity meter (CM-30V).

\subsection{Synthesis of poly (o-phenylenediamine - Co -o/p- toluidine)copolymer}

\subsubsection{Synthesis of poly o-phenylenediamine}

The polymer of $o$-phenylenediamine was synthesized by dissolving $1.622 \mathrm{~g}$ of $o$-phenylenediamine in $100 \mathrm{~mL}$ of $0.1 \mathrm{M} \mathrm{HCL}$ in a stirred ice bath to produce a homogenous solution. $4.413 \mathrm{~g}$ of potassium dichromate was dissolved in $50 \mathrm{~mL}$ of $0.1 \mathrm{M} \mathrm{HCL}$ and added to the first solution for $30 \mathrm{~min}$ while being constantly stirred, then it was left at room temperature for $24 \mathrm{~h}$. After this the solution was filtered, washed with acetone and distilled water and the polymer was left to dry in an oven at $60{ }^{\circ} \mathrm{C}$ for $24 \mathrm{~h}$.

\subsubsection{Synthesis of poly $o$ - and p-toluidine}

Poly ( $o$ - and $p$-toluidine) were synthesized with chemical oxidative polymerization of $o$ - and $p$ - toluidine in an acidic media. $5 \mathrm{~mL}$ of $o \mathrm{~T}$ was dissolved in $300 \mathrm{~mL}$ of $1 \mathrm{M}$ formic acid and kept at $0{ }^{\circ} \mathrm{C} ; 11.4 \mathrm{~g}$ of $\mathrm{K}_{2} \mathrm{Cr}_{2} \mathrm{O}_{7}$ was dissolved in $200 \mathrm{~mL}$ of $1 \mathrm{M}$ formic acid also at $0{ }^{\circ} \mathrm{C}$ and added dropwise under constant stirring to the $(o \mathrm{~T} / \mathrm{HCOOH})$ solution over a period of $20 \mathrm{~min}$. The resulting dark green solution was maintained under constant stirring for $24 \mathrm{~h}$. The solution was filtered and then washed with distilled water; the black powder of poly $o$-toluidine was left to dry in air for one week, while 2.5 $\mathrm{mL}$ of $p \mathrm{~T}$ was dissolved in $150 \mathrm{~mL}$ of $1 \mathrm{M} \mathrm{HCL}$ and kept at $0{ }^{\circ} \mathrm{C} ; 5.7 \mathrm{~g}$ of $\mathrm{K}_{2} \mathrm{Cr}_{2} \mathrm{O}_{7}$ was also dissolved in $100 \mathrm{~mL}$ of $1 \mathrm{M} \mathrm{HCL}$ at $0{ }^{\circ} \mathrm{C}$ and added dropwise under constant stirring to the $(p \mathrm{~T} / \mathrm{HCL})$ solution over a period of $20 \mathrm{~min}$. The resulting dark red solution was maintained under constant stirring for $24 \mathrm{~h}$. The solution was filtered and then washed with distilled water, and the black red powder of poly $p$-toluidine was left to dry in air for one week.

\subsubsection{Synthesis of poly (o-phenylenediamine - Co- $o-/ p$ - toluidine) copolymer}

$1.54 \mathrm{~g} o \mathrm{PD}$ and $0.5133 \mathrm{~mL} o \mathrm{~T} / p \mathrm{~T}$ were added to $150 \mathrm{~mL}$ of $1 \mathrm{M}$ glacial acetic acid in a $500 \mathrm{~mL}$ singleneck glass flask at $40{ }^{\circ} \mathrm{C} .13 .68 \mathrm{~g}\left(\left(\mathrm{NH}_{4}\right)_{2} \mathrm{~S}_{2} \mathrm{O}_{8}\right)$ was dissolved separately in $14 \mathrm{~mL}$ distilled water to prepare an oxidant solution. The monomer solution was then stirred and treated with the oxidant solution added dropwise at an adding rate of one drop every three seconds for $30 \mathrm{~min}$ at $40{ }^{\circ} \mathrm{C}$. Immediately after the first few drops, the reaction solution turned violet in the case of $o \mathrm{~T}$ and blackish green in the case of $p \mathrm{~T}$. After $1 \mathrm{~h}$, the copolymer acetate was isolated from the reaction mixture with filtration and washed with the excess of distilled water to remove the oxidant and oligomers. A whitish

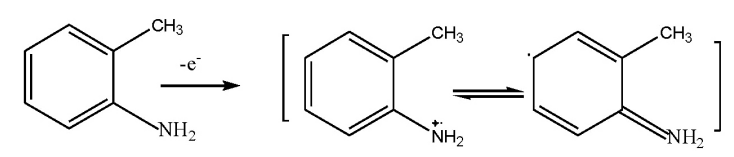<smiles>Nc1ccccc1N</smiles><smiles>CC1=CC(=Nc2ccccc2N)C=CC1=Nc1ccc(Nc2ccc(N)c(C)c2)c(N)c1</smiles><smiles>Cc1ccc(Nc2ccc(Nc3ccccc3C)cc2N)cc1N</smiles><smiles>Cc1cc(N=C2C=CC(=Nc3ccccc3C)C=C2N)ccc1N</smiles>

Figure 1: Scheme of copolymerization mechanism of poly (o-phenylenediamine-Co-o-toluidine) copolymer

Slika 1: Shema mehanizma kopolimerizacije poli ( $o$-fenilendiamin in $o$-toluidin) kopolimera 
O. MELAD, M. JAROUR: COPOLYMERIZATION OF POLY (O-PHENYLENEDIAMINE-CO-O/P-TOLUIDINE) VIA ...

violet solid powder and a greenish brown solid powder for $o \mathrm{~T}$ and $p$-T copolymers, respectively, were left to dry in the oven at $118{ }^{\circ} \mathrm{C}$ for $48 \mathrm{~h}$ and then dry in air for one week. The above procedure was repeated at various molar ratios of the monomers $o \mathrm{~T}$ and $p \mathrm{~T}$ at the feeds of 0.50 and 0.25 molar of $o \mathrm{PD}$, respectively.

\section{RESULTS AND DISCUSSION}

\subsection{Synthesis of poly (o-phenylenediamine - Co-o-/p- toluidine)copolymer}

Toluidines are derivatives of aniline where a $-\mathrm{CH}_{3}$ group is substituted in the aromatic ring at the $o-, m$ - or $p$ - positions. Schemes in Figures 1 and $\mathbf{2}$ represent the copolymerization mechanism of poly (o-phenylenediamine-Co- $o$ - $/ p$-toluidine)copolymer, respectively.

\subsection{FTIR spectra of poly (o-phenylenediamine - Co - o / p- toluidine) copolymer}

Figure 3 shows the FTIR spectra of poly $o$-phenylenediamine, poly $o$-toluidine and poly $p$-toluidine, respectively.<smiles>Cc1ccc(N)c(CCN)c1</smiles><smiles>CC1(Nc2ccccc2N)C=CC(=N)C=C1</smiles><smiles>[3H]N(c1ccc(C)cc1)c1ccc(NC2(C)C=C(N)C(c3ccc(N)cc3)=CC2)c(N)c1</smiles><smiles>Cc1ccc(N=C2C=CC(=NC3(C)C=CC(N)=CC3)C(N)=C2)cc1</smiles>

Figure 2: Scheme of copolymerization mechanism of poly (o-phenylenediamine-Co- $p$-toluidine) copolymer

Slika 2: Shema mehanizma kopolimerizacije poli ( $o$-fenilendiamin in $p$-toluidin) kopolimera

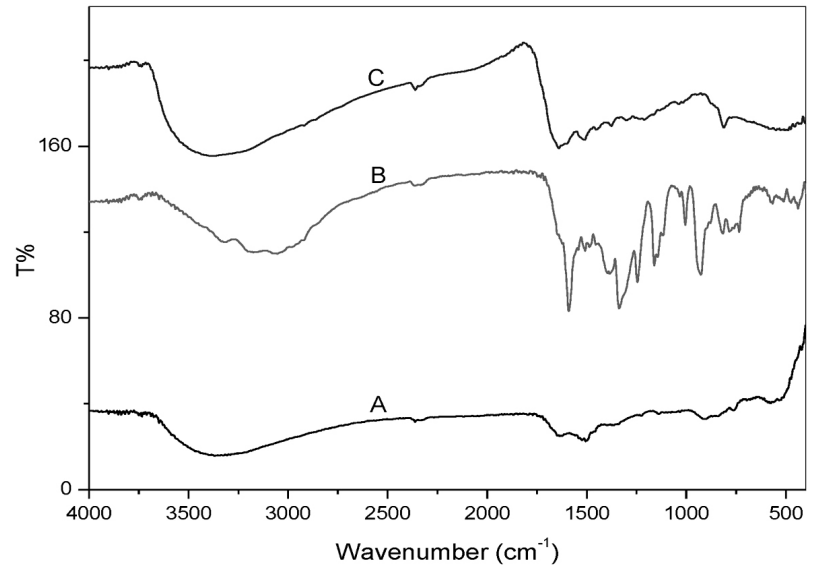

Figure 3: FTIR spectra of: A) poly $o$-phenylenediamine, B) poly $o$-toluidine and C) poly $p$-toluidine

Slika 3: FTIR-spekter: A) poli $o$-fenilendiamina, B) poli $o$-toluidina in C) poli $p$-toluidina

A weak band is observed at $3326-3391 \mathrm{~cm}^{-1}$ characteristic of the $-\mathrm{NH}_{2}$ and $\mathrm{N}-\mathrm{H}$ stretching, another one is observed at $1640-1525 \mathrm{~cm}^{-1}$ assigned to the quinoid and benzenoid phenyl ring for poly o-phenylenediamine (Figure 3 (A), the signal due to the $\mathrm{C}-\mathrm{H}$ in-plane bending vibratio is observed at $1161 \mathrm{~cm}^{-1}$. Figure $3(\mathrm{~B}$ and C) shows the frequency peaks at $(2917,1638,1450$, $1301,1207,1157,920) \mathrm{cm}^{-1}$ that are attributed to the $\mathrm{C}-\mathrm{H}$ stretching of the substituent methyl group, $\mathrm{C}=\mathrm{C}$ stretching vibrations of quinoid rings, $\mathrm{C}=\mathrm{C}$ stretching vibrations of benzoid rings, $\mathrm{C}-\mathrm{N}$ stretching vibrations of quinoid rings, $\mathrm{C}-\mathrm{N}$ stretching vibrations of benzoid rings, $\mathrm{C}-\mathrm{H}$ in-plane bending vibrations and 1, 2, 4- tri substituted aromatic rings, respectively. The signal at $567 \mathrm{~cm}^{-1}$ is due to the C-H out-of-plane bending vibration. The peak at $3063 \mathrm{~cm}^{-1}$ in Figure 3 (B and C) is caused by the $\mathrm{C}-\mathrm{H}$ stretch modes of the substituent methyl group. Figure 4 shows the FTIR spectra of poly

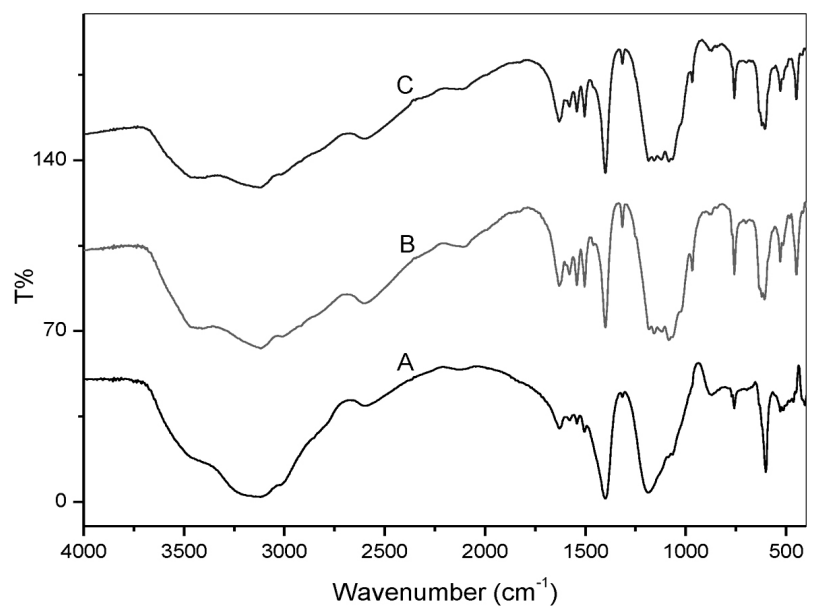

Figure 4: FTIR spectra of poly (oPD-Co- $o$ T) copolymer with different molar ratios of $o$ PD: A) 0.25 , B) 0.50, C) 0.75

Slika 4: FTIR-spektri poli ( $o \mathrm{PD}$ in $o \mathrm{~T}$ ) kopolimera $\mathrm{z}$ različnimi molskimi razmerji $o$ PD: A) 0,25, B) 0,50, C) 0,75 
$(o \mathrm{PD}-\mathrm{Co}-o \mathrm{~T})$ copolymer with different molar ratios of $o \mathrm{PD}$.

Most of the bands show variations in the intensity and position. The spectra of the copolymer show the main bands corresponding to the $\mathrm{N}-\mathrm{H}$ stretching vibrations and ring stretching vibrations of quinoid and benzeoid structures. The intensity of the N-H stretching vibrations in the region between $3470-3010 \mathrm{~cm}^{-1}$ increases with the increasing $o \mathrm{PD}$ feed concentration, indicating an increase in the number of primary and secondary amino groups in the copolymer structure. The band at $1590 \mathrm{~cm}^{-1}$ (Figure 3 (B)) and the band at 1627 $\mathrm{cm}^{-1}$ (Figure $3(\mathrm{C})$ ) correspond to the $\mathrm{C}=\mathrm{C}$ stretching vibrations of the aromatic rings. This signal is shifted to $1630 \mathrm{~cm}^{-1}$ in the copolymer, Figure 4 . The intensity of the two bands centered at $1497 \mathrm{~cm}^{-1}$ and $600 \mathrm{~cm}^{-1}$ greatly increases with the increasing $o \mathrm{PD}$ feed concentration (Figure 4), while the $1497 \mathrm{~cm}^{-1}$ band in the copolymer indicates the presence of phenazine-type structures in the copolymer backbone. These cyclic structures in the copolymer are either due to the presence of $o \mathrm{PD}$ blocks or may result from the cyclization of the adjacent $o \mathrm{PD}$ and $o \mathrm{~T}$ units in the copolymer chain. On the other hand, the intensity of the band at $1005 \mathrm{~cm}^{-1}$, due to the $-\mathrm{CH}_{3}$ bending vibrations, substantially decreases in the copolymer. This is indicative of a gradual decrease in the $o \mathrm{~T}$ units in the copolymer structure with the increasing $o$ PD feed concentration.

Figure 5 shows the FTIR spectra of poly $(o$ PDCo- $p \mathrm{~T}$ ) copolymer with different molar ratios of $o \mathrm{PD}$.

In general, with some exceptions, the spectral characteristics of the copolymers are very similar to those of $\mathrm{PoPD}$. The intensity of the broad band, in the region of $3000-3353 \mathrm{~cm}^{-1}$ increases with the increasing $o$ PD feed concentration. The band corresponding to the quinoid stretching vibrations occurs at $1616 \mathrm{~cm}^{-1}$ for the copolymer. The intensity of this band was also found to increase with the increasing $o \mathrm{PD}$ feed concentration. The

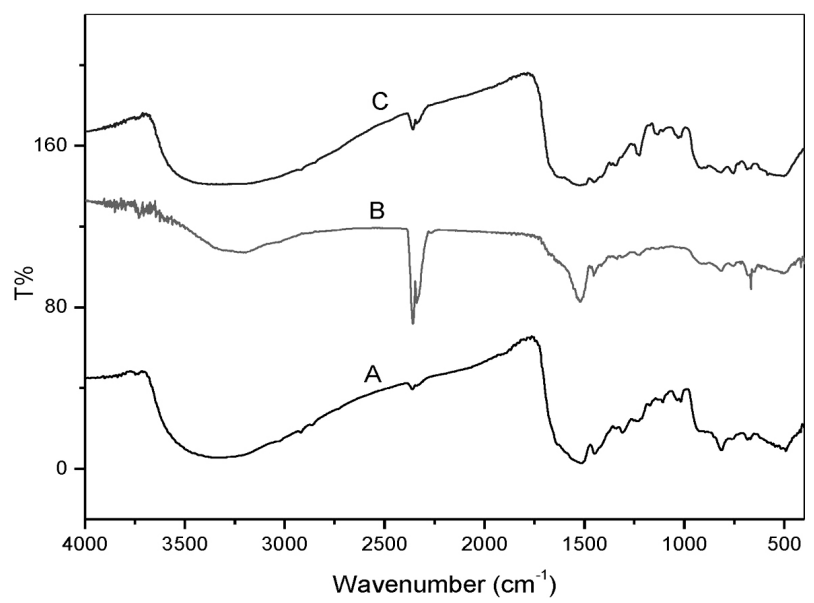

Figure 5: FTIR spectra of poly (oPD-Co- $P$ T) copolymer with different molar ratios of $o$ PD: A) 0.25 , B) 0.50 , C) 0.75

Slika 5: FTIR-spektri poli ( $o$ PD in $\mathrm{PT}$ ) kopolimera $\mathrm{z}$ različnimi molskimi razmerji $o \mathrm{PD}$ : A) 0,25 , B) 0,50 in C) 0,75

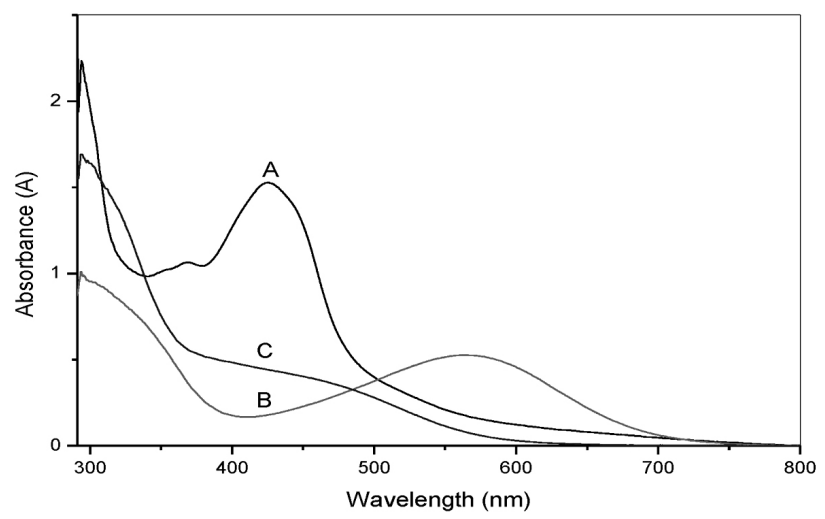

Figure 6: UV-VIS spectra of: A) poly $o$-phenylenediamine, B) poly $o$-toluidine and C) $p$-toluidine

Slika 6: UV-VIS spektri: A) poli $o$-fenilendiamin, B) poli $o$-toluidin in C) $p$-toluidin

incorporation of the p-toluidine moiety in the copolymer was indicated by the appearance of the characteristic C-H stretching of the substituent methyl group, which was observed as a very weak band at $2917 \mathrm{~cm}^{-1}$. As in o-toluidine, the intensity of the band at $1029 \mathrm{~cm}^{-1}$, due to the $-\mathrm{CH}_{3}$ bending vibrations, substantially decreases in the copolymer.

\subsection{UV-visible spectra of poly (o-phenylenediamine - Co - o / p-toluidine) copolymer}

Figure 6 shows the UV-visible spectra of poly $o$-phenylenediamine, poly $o$-toluidine and poly $p$-toluidine, respectively.

Figures 7 and 8 show the UV-visible spectra of poly $(o \mathrm{PD}-\mathrm{Co}-o \mathrm{~T})$ and poly ( $o$ PD-Co- $p \mathrm{~T})$ copolymers, respectively, with different molar ratios of $o$ PD. In Figures 6, 7 and $\mathbf{8}$, for UV-visible spectra of homopolymers and copolymers, two characteristic absorption peaks were found at around $290 \mathrm{~nm}$ and in a range of 417-563 nm corresponding to the benzene $\pi-\pi^{*}$ electronic transition and $\mathrm{n}-\pi^{*}$ electronic transition. A hyposochromic shift from $550 \mathrm{~nm}$ in the o-toluidine copolymer to $450 \mathrm{~nm}$ in

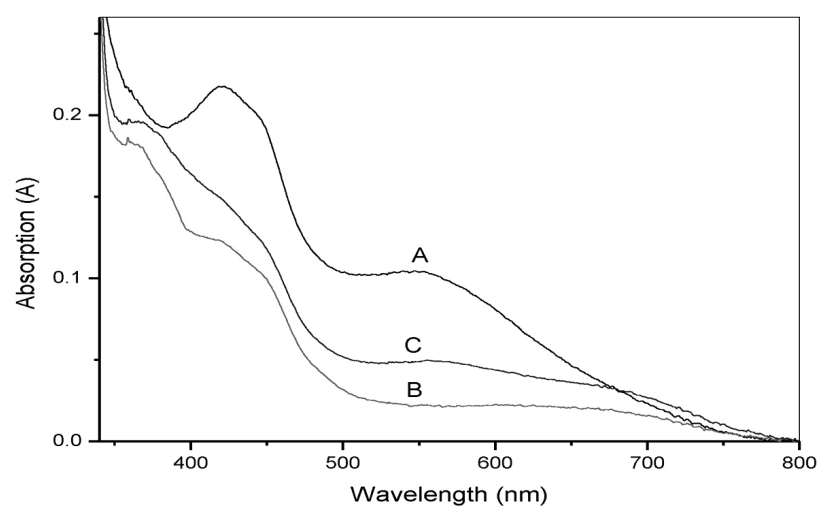

Figure 7: UV-VIS spectra of poly ( $o$ PD-Co- $o \mathrm{~T})$ copolymer with different molar ratios of $o$ PD: A) 0.25 , B) 0.50 and C) 0.75

Slika 7: UV-VIS spektri poli ( $o$ PD in $o \mathrm{~T}$ ) kopolimera z različnimi molskimi razmerji oPD: A) 0,25 , B) 0,50 in C) 0,75 


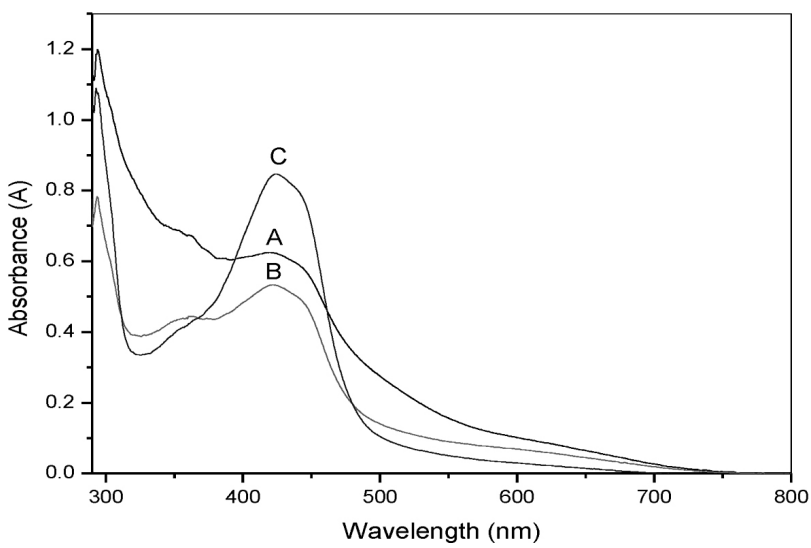

Figure 8: UV-VIS spectra of poly $(o \mathrm{PD}-\mathrm{Co}-p \mathrm{~T})$ copolymer with different molar ratio of $o$ PD: A) 0.25 , B) 0.50 and C) 0.75 .

Slika 8: UV-VIS spektri poli $(o \mathrm{PD}$ in $p \mathrm{~T})$ kopolimera $\mathrm{z}$ različnimi molskimi razmerji $o$ PD: A) 0,25 , B) 0,50 in C) 0,75

the p-toluidine copolymer implies a decrease in the extent of conjugation and an increase in the band gap. These bands correspond to the excitation transition of the quinoid rings. It can be observed that these bands increase when the o-phenylenediamine in the copolymer is increased. This blue shift with the increasing o-phenylenediamine in the copolymer is due to the steric effect of the substituents, indicating a successful copolymerization.

\subsection{Electrical conductivity}

Table 1: shows electrical conductivity of poly (o-phenylenediamine -Co-o/p-toluidine) copolymer at room temperature in DMF

Tabela 1: Električna prevodnost poli (o-fenilendiamina in $o / p$-toluidin) kopolimera pri sobni temperaturi v DMF

\begin{tabular}{|c|c|}
\hline Polymer & Conductivity $(\mathrm{S} / \mathrm{cm})$ \\
\hline $\mathrm{P} o \mathrm{PD}$ & 2.23 \\
\hline $\mathrm{P} o \mathrm{~T}$ & 1.43 \\
\hline $\mathrm{P} p \mathrm{~T}$ & 2.04 \\
\hline $\mathrm{P}(o \mathrm{PD}-\mathrm{Co}-o \mathrm{~T}) 25$ & 3.39 \\
\hline $\mathrm{P}(o \mathrm{PD}-\mathrm{Co}-o \mathrm{~T}) 50$ & 3.42 \\
\hline $\mathrm{P}(o \mathrm{PD}-\mathrm{Co}-o \mathrm{~T}) 75$ & 4.65 \\
\hline $\mathrm{P}(o \mathrm{PD}-\mathrm{Co}-p \mathrm{~T}) 25$ & 1.615 \\
\hline $\mathrm{P}(o \mathrm{PD}-\mathrm{Co}-p \mathrm{~T}) 50$ & 1.878 \\
\hline $\mathrm{P}(o \mathrm{PD}-\mathrm{Co}-p \mathrm{~T}) 75$ & 1.898 \\
\hline
\end{tabular}

It can be seen that the conductivity increases as the amount of $o$-phenylenediamine increases in the copolymers. In general, o-isomer gives higher conductivity values than the other isomers; the small values of the conductivity in the case of poly (o-phenylenediamine-Co-p-toluidine) copolymer compared with the conductivity value of $o$-phenylenediamine may indicate that $p$-toluidine is not a good enough polymer to make a copolymer with $o$-phenylenediamine.

\section{CONCLUSION}

The synthesis of the copolymerization of $o$-phenylenediamine with $o$ / $p$-toluidine was characterized using FTIR and UV-Vis spectroscopy. The intensity of the band at $1005 \mathrm{~cm}^{-1}$ that is due to the $-\mathrm{CH}_{3}$ bending vibrations, substantially decreases in the copolymer. A hypsochromic shift from $550 \mathrm{~nm}$ in the $o$-toluidine copolymer to $450 \mathrm{~nm}$ in the $p$-toluidine copolymer implies a decrease in the extent of conjugation and an increase in the band gap. In general, ortho-isomers give higher conductivity values than the other isomers; so the obtained conductivity values that are higher for the $o$-toluidine copolymer than for the $p$-toluidine copolymer, indicate that $p$-toluidine is not a good enough polymer able to make a copolymer with $o$-phenylenediamine.

\section{REFERENCES}

${ }^{1}$ E. Hrehorova, V. N. Bliznyuk, A. A. Pud, V. V. Shevchenko, K. Y. Fatyeyeva, Electrical properties and fractal behavior of polyurethane elastomer/polyaniline composites under mechanical deformation, Polymer, 48 (2007), 4429-4437, doi:10.1016/j.polymer.2007.05.065 ${ }^{2}$ P. Wang, L. Liua, D. A. Mengistiec, B. Wen, T. Liue, C. Chuf, Transparent electrodes based on conducting polymers for display applications, Displays, 34 (2013), 301-314, doi:10.1016/j.displa.2013.05. 003

${ }^{3}$ M. Jaymand, Recent progress in chemical modification of polyaniline, Prog.Polym.Sci., 38 (2013), 1287-1306, doi:10.1016/j.progpolymsci.2013.05.015

${ }^{4}$ X. Guo, M. Baumgarten, K. Mullen, Designing $\pi$-conjugated polymers for organic electronics, Prog.Polym.Sci., 38 (2013), 1832-1908, doi:10.1016/j.progpolymsci.2013.09.005

${ }^{5}$ Y. Zhao, S. Si, C. Liao, A single flow zinc//polyaniline suspension rechargeable battery, J. Power Sources, 241 (2013), 449-453, doi:10.1016/j.jpowsour.2013.04.095

${ }^{6}$ C. Steffens, A. Manzoli, J. E. Oliveira, F. L. Leite, D. S. Correa, P. Herrmann, Bio-inspired sensor for insect pheromone analysis based on polyaniline functionalized AFM cantilever sensor, Sensors and Actuators, B191 (2014), 643-649, doi:10.1016/j.snb.2013.10.053

${ }^{7}$ L. Wang, E. Hua, M. Liang, C. Ma, Z. Liu, S. Sheng, Liu Min, G. Xie, W. Feng, Biosensors, 51C (2014), 201-207, doi:10.1016/j.bios. 2013.07.049

${ }^{8}$ Y. Moon, J. Yun, H. Kim, Synergetic improvement in electromagnetic interference shielding characteristics of polyaniline-coated graphite oxide/ $\gamma$-Fe2O3/BaTiO3 nanocomposites, J. Ind. Eng. Chem., 19 (2013),493-497, doi:10.1016/j.jiec.2012.09.002

${ }^{9}$ G. Gupta, N. Birbilis, A. B. Cook, A. S. Khanna, Polyanilinelignosulfonate/epoxy coating for corrosion protection of AA2024-T3, Corros. Sci. 67 (2013), 256-267, doi:10.1016/j.corsci. 2012.10.022

${ }^{10}$ K. Gopodinova, L. Terlemezyan, Conducting polymers prepared by oxidative polymerization: polyaniline, Progress in Polym. Sci., 38 (1998), 1832-1908

${ }^{11}$ K. Gurunathan, A. V. Murugan, R. Marimuthu, U. P. Mulik, D. P. Amalnerkar, Electrochemically synthesised conducting polymeric materials for applications towards technology in electronics, optoelectronics and energy storage devices, Materials Chem. and Phys., 61 (1999), 173-191, doi:10.1016/S0254-0584(99)00081-4

${ }^{12}$ P. Chowdhury, B. Saha, Indian J. Chem. Tech., 12 (2005), 671-675

${ }^{13}$ S. M. Sayyah, A. B. Khaliel, A. A. Aboud and S. M. Mohamad, Chemical Polymerization Kinetics of Poly-O-Phenylenediamine and Characterization of the Obtained Polymer in Aqueous Hydrochloric 


\section{MATERIALI IN TEHNOLOGIJE/MATERIALS AND TECHNOLOGY (1967-2017) - 50 LET/50 YEARS}

\section{O. MELAD, M. JAROUR: COPOLYMERIZATION OF POLY (O-PHENYLENEDIAMINE-CO-O/P-TOLUIDINE) VIA ...}

Acid Solution Using K2Cr2O7 as Oxidizing Agent, Int. J. Polym. Sci., (2014), 1-16, doi:10.1155/2014/520910

${ }^{14}$ O. Melad, Chemical Oxidative Synthesis and Characterization of Poly (o-phenylenediamine) Doped With Different Acids, Eur. J. Chem., 7 (2016) 4, 463-467, doi:10.5155/eurjchem.7.4.463-467. 1449

${ }^{15}$ R. Hirase, T. Shikata, M. Shirai, Selective formation of polyaniline on wool by chemical polymerization, using potassium iodate, Synth. Met., 146 (2004), 73-77, doi:10.1016/j.synthmet.2004.06.009

${ }^{16}$ K. Gopalakrishnan, M. Elango, M. Thamilsevan, Optical studies on nano-structured conducting Polyaniline prepared by chemical oxidation method, Archives of Phys. Research, 3 (2012), 315-319

${ }^{17}$ K. Molapo, P. M. Ndangili, R. F. Ajayi, Electronics of Conjugated Polymers (I): Polyaniline, Int. J. Electrochem. Sci., 7 (2012), 11859-11875

${ }^{18}$ Y. Cao, P. Smith, A. Heeger, Counter-ion induced processibility of conducting polyaniline and of conducting polyblends of polyaniline in bulk polymers, Synth. Met., 48 (1992), 91-97

${ }^{19}$ A. H. Premasiri, W. B. Euler, Syntheses and characterization of poly(aminophenazines), Macromol. Chem. Phys., 196 (1995), 3655

${ }^{20}$ H. S. O. Chan, S. C. Nig, T.S.A. Hor, J. Sun, K. L. Tan, B. T. G. Tan, Poly( $m$-phenylenediamine): Synthesis and characterization by X-ray photoelectron spectroscopy, Eur. Polym. J., 27 (1991), 1303

${ }^{21} \mathrm{~F}$. Cataldo, On the polymerization of p-phenylenediamine, Eur. Polym. J., 36 (1996), 2593

${ }^{22}$ A. Malinauskas, M. Bron, R. Holze, Electrochemical and Raman spectroscopic studies of electrosynthesized copolymers and bilayer structures of polyaniline and poly(o-phenylenediamine), Synthetic metals, 92 (1998), 127-137, doi:10.1016/S0379-6779(98)80102-1

${ }^{23}$ X. G. Li, L. X. Wang, Y. Jin, Z. L. Zhu, Y. L. Yang, Preparation and identification of a soluble copolymer from pyrrole and o-toluidine, Journal of applied polymer science, 82 (2001), 510-518
${ }^{24}$ Y. Wei, R. Hariharan, S. A. Patel, Chemical and electrochemical copolymerization of aniline with alkyl ring-substituted anilines, Macromolecules, 23 (1990), 758, doi:10.1021/ma00205a011

${ }^{25}$ N. Pekmez - Ozcicek, K. Pekmez, R. Holze, A.Yildiz, Increased stability of polythiophene in the presence of aniline in acetonitrile, J. Appl. Polym. Sci., 89 (2003), 862, doi:10.1002/app.12291

${ }^{26}$ Y. Sahin, S. Percin, M. Sahin, G. Ozkan, Electrochemical polymerization of fluoro- and chloro-substituted anilines and copolymers with aniline, J. Appl. Polym. Sci., 91 (2004), 2302, doi:10.1002/ app.133677

${ }^{27}$ P. Savita, D. N. Sathyanarayana, Copolymers of aniline withoandm-toluidine: synthesis and characterization, Polym. Int., 53 (2004), 106, doi:10.1002/pi.1316

${ }^{28}$ P. Savita, D. N. Sathyanarayana, Synthesis and characterization of soluble conducting poly(o-/m-toluidine-co-o-nitroaniline), Synth. Met., 145 (2004), 113, doi:10.1016/j.synthmet.2004.04.024

${ }^{29}$ H. Tang, A. Kitani, S. Maitani, H. Munemura, M. Shiotanti, Electropolymerization of aniline modified by para-phenylenediamine, Electrochim. Acta, 40 (1995), 849, doi:10.1016/0013-4686(94) 00370-G

${ }^{30}$ R. Mazeikiene, A. Malinauskas, Electrochemical copolymerization of aniline with m-phenylenediamine, Synth. Met., 92 (1998), 259

${ }^{31}$ M. Probst, R. Holze, A systematic spectroelectrochemical investigation of alkyl-substituted anilines and their polymers, Macromol. Chem. Phys., 198 (1997), 1499, doi:10.1002/macp.1997.021980515

${ }^{32}$ O. Melad, H. Alhendawi, M. Fayyad, Research and Reviews: J. Material Sci., 2 ( 2014), 27-34

${ }^{33}$ O. Melad, M. Esleem, Copolymers of Aniline with O-Anthranilic Acid: Synthesis and Characterization, Open J. Org. Polym. Materials, 5 (2015), 31-36, doi:10.4236/ojopm.2015.52003

${ }^{34} \mathrm{~S}$. Bilal, R. Holze, Electrochemical copolymerization of o-toluidine and o-phenylenediamine, J. Electroanalytical Chem., 592 (2006), 1-13, doi:10.1016/j.jelechem.2006.03.039 